\title{
Evaluation of Nocturia in Patients with Obstructive Sleep Apnea Syndrome
}

\section{Obstrüktif Uyku Apne Sendromlu Hastalarda Noktürinin Değerlendirilmesi}

\author{
Bora İrer', Aylin Çelikhisar², Hakan Çelikhisar², Ozan Bozkurt ${ }^{3}$, Ömer Demir ${ }^{3}$ \\ ${ }^{1}$ İzmir Metropolitan Municipality Eşrefpaşa Hospital, Clinic of Urology, Izmir, Turkiye \\ ${ }^{2}$ Izmir Metropolitan Municipality Eşrefpaşa Hospital, Clinic of Chest Diseases, İzmir, Turkiye \\ ${ }^{3}$ Dokuz Eylül University Faculty of Medicine, Department of Urology, Izmir, Turkiye
}

What's known on the subject? and What does the study add?

Nocturia and obstructive sleep apnea syndrome significantly decrease general health-related quality of life. Nocturia is commonly reported in patients with obstructive sleep apnea syndrome. This study aims to increase awareness of nocturia when evaluating and treating patients with obstructive sleep apnea syndrome.

\section{Abstract}

Objective: This study aims to increase awareness of nocturia when evaluating and treating patients with Obstructive Sleep Apnea syndrome (OSAS). Materials and Methods: A total of 324 patients, who attended our sleep center with the suspected diagnosis of OSAS between June 2012 and December 2015, participated in our research. The patients were divided into 4 groups according to age distribution. Demographic variables, comorbid conditions and severity of OSAS were evaluated retrospectively for their association with the nocturia.

Results: In this study, 176 patients had nocturia and 148 patients did not have. There was a statistically significant difference in the presence of nocturia between patients with and without OSAS $(p \leq 0.001)$. We found that the prevalence of nocturia was higher in the severe OSAS group than in the moderate and the mild OSAS and normal groups $(\mathrm{p} \leq 0.001)$. We demonstrated that there were statistically significant differences in the frequency of nocturia and total apnea-hypopnea index between OSAS groups and age groups ( $\mathrm{p} \leq 0.001)$. There was a statistically significant but weak correlation between nocturia and severity of OSAS and between frequency of nocturia and OSAS severity $(r=0.310$, $p \leq 0.001$ and $r=0.276$, $\mathrm{p} \leq 0.001)$. This relationship was more significant in women than in men and more significant in patients below age 40 than in the other age groups. However, we could not find any significant difference in the presence of nocturia between patients with and without comorbid diseases.

Conclusion: The frequency of nocturia increases as the severity of OSAS increases and especially patients with OSAS below age 40 years should be evaluated for nocturia.

Keywords: Nocturia, Sleep Apnea syndrome, Quality of life

Öz

Amaç: Bu çalışmada, Obstrüktif Uyku Apne sendromlu (OUAS) hastalar değerlendirilirken ve tedavi edilirken noktürinin farkındalığının arttırılması amaçlanmaktadır.

Gereç ve Yöntem: Haziran 2012 Aralık - 2015 tarihleri arasında uyku kliniğimize OUAS şüphesi ile başvuran 324 hasta çalışmamıza dahil edildi. Hastalar yaş dağılımlarına göre 4 gruba ayrıldı. Hastaların demografik verilerinin, komorbiditelerinin ve OUAS şiddetlerinin noktüri ile ilişkileri geriye dönük olarak değerlendirildi.

Bulgular: Çalışmada 176 hastada noktüri varlığı saptanırken 148 hastada noktüri yoktu. OUAS olan ve olmayan hastalar arasında noktüri bulunması yönünden istatistiksel olarak anlamlılık vardı $(p \leq 0,001)$. Noktüri varlığı, şiddetli OUAS olan hastalarda orta OUAS'li, ılımlı OUAS'li hastalar ve normal hastalara göre daha yüksek saptandı $(p \leq 0,001)$. Noktüri sıklığı ve toplam AHI skorları için OUAS grupları ve yaş grupları arasında istatistiksel olarak anlamlı fark bulundu $(p \leq 0,001)$. Noktüri ve OUAS şiddeti arasında ve noktüri sıklığı ile OUAS şiddeti arasında istatiksel olarak anlamlı ama zayıf bir

Correspondence: Bora İrer MD, İzmir Metropolitan Municipality Eşrefpaşa Hospital, Clinic of Urology, İzmir, Turkiye

Phone: +90 5055250995 E-mail: borairer@yahoo.com ORCID-ID: orcid.org/0000-0002-7719-9033

Received: 05.09.2017

Accepted: 05.12.2017

Cite this article as: İrer B, Çelikhisar A, Çelikhisar H, Bozkurt O, Demir Ö. Evaluation of Nocturia in Patients with Obstructive Sleep Apnea Syndrome.

J Urol Surg 2018;5(1):25-29.

๑Copyright 2018 by the Association of Urological Surgery / Journal of Urological Surgery published by Galenos Publishing House. 
ilişki vardı ( $r=0,310 p \leq 0,001$ ve $r=0,276 p \leq 0,001)$. Bu ilişki kadınlarda erkeklere göre ve 40 yaşın altındaki hastalarda diğer yaş gruplarına göre daha anlamlıydı. Ancak çalışmamızda noktüri varlığı için komorbitidesi olan ve olmayan hastalarda istatistiksel fark gözlenmedi.

Sonuç: Noktüri sıklığı arttıkça OUAS şiddeti de artmaktadır ve özellikle 40 yaş altındaki OUAS'li hastalar noktüri varlığı açısından değerlendirilmelidirler. Anahtar Kelimeler: Noktüri, Uyku Apne sendromu, Yaşam kalitesi

\section{Introduction}

Nocturia is defined by the International Continence Society as a complaint that an individual has to wake at night one or more times to void and each void is preceded and followed by sleep (1). The prevalence of nocturia increases with age. The prevalence rate is $3.4 \%$ for males under 30 and 32.4\% for males over 60 years of age (2). The most common causes of nocturia in men and women are benign prostatic hyperplasia, overactive bladder and reduced bladder capacity. Nocturia is also found to be associated with medications such as diuretics and analgesics. However, nocturia can signify possible contribution of numerous systemic health- related disorders, such as diabetes mellitus, diabetes insipidus, anorexia nervosa, congestive heart failure causing peripheral edema, and Obstructive Sleep Apnea syndrome (OSAS) (3). OSAS is one of the most common respiratory disorders. It is characterized by recurrent occlusion of breathing in the upper airway, affecting up to $20 \%$ of the general population $(3,4)$. OSAS as defined by an apnea-hypopnea index (AHI) of $\geq 5$ diagnosed by polysomnography (PSG) is commonly associated with obesity, hypertension and diabetes $(4,5)$. Nocturia is commonly reported in patients with OSAS. However, the causes of nocturia in patients with OSAS are not well understood. Possible pathophysiologycal mechanisms of nocturia involve large negative swings in intrathoracic pressure resulting in cardiac mediated diuresis and due to effects of atrial natriuretic peptide (ANP) which is a strong vasodilator polypeptide secreted by the atrial myocytes in response to hypoxia (6). Increased secretion of natriuretic peptides may be associated with nocturnal urine production. The functions of antidiuretic hormone, arginine vasopressin, and the renin angiotensin-aldosterone system, which may induce nocturnal urination, are suppressed by $\operatorname{ANP}(6,7)$. It is well known that nocturia and OSAS significantly decrease general health-related quality of life (HROL) (8). Recent published data has shown that nocturia may be a predictive symptom of OSAS (9). In addition, previous clinical studies demonstrated that continuous positive airway pressure (CPAP) may reduce nocturia in patients with OSAS and the frequency of nocturia tends to decrease when OSA is treated with CPAP (10). In this study, we investigated the prevalence of nocturia and frequency of nocturnal urination in patients with mild, moderate and severe OSAS defined according to AHI scores.

\section{Materials and Methods}

We retrospectively evaluated the PSG recordings of 324 patients who attended our sleep center between June 2012 and December 2015 with suspected OSAS and stayed one night. OSAS was diagnosed in our sleep laboratory according to full-night PSG results using a digital PSG system (Grass Technologies Comet As40 Amplifier Diagnostic Sleep System). Patients with an AHI score of $<5$ were labeled as having simple snoring (normal), patients with an $\mathrm{AHI}$ score between 5 and 15 were diagnosed with mild OSAS, patients with an $\mathrm{AHI}$ score between 15 and 30 were diagnosed with moderate OSAS, and patients with an $\mathrm{AHI}$ value of $\geq 30$ were diagnosed with severe OSAS (11). The patients were divided into 4 groups according to age. Patients under the age of 40 , between the age of 40 and 49, between the age of 50 and 59 and over the age of 60 were defined as group 1, group 2, group 3 and group 4, respectively. Nocturia was defined as the need to awaken $\geq 1$ times per night for urination (1). Frequency of nocturia was determined using the PSG records, night time observation forms and video records. Patients with nocturia were included only if they suffered from nocturia affecting daily life activities. The frequency of nocturia was defined as the total times of urination between going to bed to sleep and leaving the bed to get up.

Patients with a history of surgical treatment of benign prostate hyperplasia (BPH) and urinary incontinence and patients receiving drug therapy for nocturia, overactive bladder and $\mathrm{BPH}$ were excluded from the study.

In this study, demographic variables such as age, gender, comorbid conditions, such as diabetes mellitus, hypertension, obesity, coronary heart disease, chronic respiratory disease, hypothyroidism and hyperthyroidism, and severity of OSAS were evaluated for their possible association with the frequency of nocturia. In this study, ethics committee approval was not obtained due to retrospective study. Informed consent was not taken because of retrospective study.

\section{Statistical Analysis}

Data of patients were analyzed using SPSS version 22 (SPSS Inc., Chicago, IL, USA). The One-Way ANOVA and correlation analysis were performed. A $p$ value of less than 0.05 was considered statistically significant.

\section{Results}

Three hundred twenty four patients (212 males and 112 females) participated in this study. A hundred seventy six patients had nocturia (54.3\%) and 148 patients (45.7\%) did not have. The prevalence of nocturia ( $\geq 1$ time per night) was similar between males and females (55.2\% vs. 52.7\%). There was no statistically 
significant difference in the presence of nocturia between patients with and without comorbid diseases. However, there was a statistically significant difference in the presence of nocturia between patients with and without OSAS $(p \leq 0.001)$. We also found that the prevalence of nocturia was higher in the severe OSAS group than in the moderate and the mild OSAS and normal groups ( $70.5 \%$ vs. $50 \%$ and $49.4 \%$ and $28.1 \%$, respectively, $p \leq 0.001$ ). The distribution of nocturia between genders, patients with or without comorbid conditions and OSAS are shown in Table 1. We demonstrated that there were statistically significant differences in the frequency of nocturia and total AHI between OSAS groups and age groups. As the frequency of nocturia increased, severity of OSAS and age also increased ( $p \leq 0.001)$. Demographic data of patients according to OSAS severity and age groups are shown in Table 2 and Table 3. In our study, a statistically significant but weak correlation was detected between nocturia and severity of OSAS and between frequency of nocturia and OSAS severity $(r=0.310, p \leq 0.001$ and $r=0.276, p \leq 0.001)$. However, this relationship was more significant in women than in men (men; $r=0.275, p \leq 0.001$ and $r=0.279 p \leq 0.001$; women; $r=0.384, p \leq 0.001$ and $r=0.335, p \leq 0.001)$. Moreover, among the age groups, in patients below the age of 40 , a statistically significant correlation was found between presence of nocturia and severity of OSAS as well as between frequency of nocturia and OSAS severity ( $r=0.493$ $p \leq 0.001$ and $r=0.446 p \leq 0.001$ ). However, this relationship was weaker in group of patients aged between 40 and $50(r=0.249$ $p \leq 0.001$ and $r=0.223$ ) and no significant correlation was found between presence of nocturia, frequency of nocturia and OSAS severity among the other age groups. We analysed our patient's chronic diseases and found that 45 patients had diabetes mellitus (13.9\%), 25 had coronary heart disease (7.7\%), 56-hypertension (17.3\%), 47-hyperlipidemia (13\%), 17-thyroid disease (5.3\%), 20 -obesity (6.2\% body mass index $\geq 30$ ), 20-chronic obstructive pulmonary disease $(6.2 \%)$ and 4 patients had cerebrovascular disease (1.2\%). We found no significant correlation between OSAS severity and these systemic diseases, but we found a weak correlation between presence of nocturia and systemic diseases $(r=0.119 p<0.05)$.

Table 1. The distribution of nocturia between genders, patients with or without comorbid conditions and Obstructive Sleep Apnea syndrome

\begin{tabular}{|c|c|c|c|c|}
\hline Patients & Nocturia (+) & Nocturia (-) & Total & $\mathbf{p}$ \\
\hline Male - n (\%) & $117(55.2)$ & $59(44.8)$ & 212 & NS \\
\hline Female - n (\%) & $59(52.7)$ & $53(47.3)$ & 112 & NS \\
\hline Comorbid conditions $(+)-\mathrm{n}(\%)$ & $75(62.0)$ & $46(38.0)$ & 121 & NS \\
\hline Comorbid conditions (-) - n (\%) & $101(49.8)$ & $102(50.2)$ & 203 & NS \\
\hline OSAS (+) - n (\%) & $158(60.8)$ & $102(39.2)$ & 260 & $\leq 0.001$ \\
\hline OSAS (-) - n (\%) & $18(28.1)$ & 46 (71.9) & 64 & $\leq 0.001$ \\
\hline
\end{tabular}

OSAS: Obstructive Sleep Apnea syndrome, NS: Not significant

Table 2. Demographic data of patients according to obstructive sleep apnea groups

\begin{tabular}{llllll}
\hline & $\begin{array}{l}\text { No OSAS } \\
\mathbf{n = 6 4}\end{array}$ & $\begin{array}{l}\text { Mild OSAS } \\
\mathbf{n}=\mathbf{3 6}\end{array}$ & $\begin{array}{l}\text { Moderate OSAS } \\
\mathbf{n = 8 5}\end{array}$ & $\begin{array}{l}\text { Severe 0SAS } \\
\mathbf{n = 1 3 9}\end{array}$ \\
\hline Age (year) & $42.3 \pm 9.8$ & $47.9 \pm 6.8$ & $48.7 \pm 10.7$ & $51.7 \pm 10.9$ & $\mathbf{p}$ \\
Total AHI & - & $9.4 \pm 3.1$ & $21.2 \pm 4.0$ & $61.8 \pm 19.9$ & $\leq .001^{*}$ \\
$\begin{array}{l}\text { Frequency of } \\
\text { nocturia }\end{array}$ & $0.5 \pm 0.8$ & $1 \pm 1.1$ & $0.9 \pm 1.0$ & $1.3 \pm 1.1$ & \\
BMI $\left(\mathrm{kg} / \mathrm{m}^{2}\right)$ & $25.2 \pm 3.6$ & $26.3 \pm 3.8$ & $24.9 \pm 3.4$ & $26.3 \pm 3.4$ & 0.1 \\
\hline
\end{tabular}

OSAS: Obstructive Sleep Apnea syndrome, AHI: Apnea-hypopnea index, BMI: Body mass index

${ }^{*}$ There is statistically significant difference between severe OSAS and the other OSAS groups

Table 3. Demographic data of patients according to age groups

\begin{tabular}{|c|c|c|c|c|c|}
\hline & $\begin{array}{l}\text { Group } 1 \\
\text { ( }<40 \text { years) } n=73\end{array}$ & $\begin{array}{l}\text { Group } 2 \\
(40-49 \text { years) } n=96\end{array}$ & $\begin{array}{l}\text { Group } 3 \\
(50-59 \text { years) } n=94\end{array}$ & $\begin{array}{l}\text { Group } 4 \\
\text { ( } \geq 60 \text { years) } n=61\end{array}$ & $\mathbf{p}$ \\
\hline Total AHI & $26.6 \pm 29.1$ & $27.4 \pm 28.8$ & $37.1 \pm 28.6$ & $44.4 \pm 26.5$ & $\leq 0.001$ \\
\hline $\begin{array}{l}\text { Frequency of } \\
\text { nocturia }\end{array}$ & $0.7 \pm 0.9$ & $0.8 \pm 0.9$ & $0.9 \pm 0.9$ & $1.9 \pm 1.2$ & $\leq 0.001^{*}$ \\
\hline $\mathrm{BMI}\left(\mathrm{kg} / \mathrm{m}^{2}\right)$ & $25.9 \pm 3.9$ & $25.7 \pm 3.0$ & $25.2 \pm 3.7$ & $26.3 \pm 3.7$ & 0.328 \\
\hline
\end{tabular}




\section{Discussion}

Nocturia is one of the most common reasons for patient's referral to urology. Whereas nocturia may have a little effect on health in some people, for others it can be a highly bothersome and debilitating condition because of disturbing impacts of nocturia on both sleep quality and HROL. The most common causes of nocturia are urologic diseases such as benign prostatic hyperplasia, overactive bladder and reduced bladder capacity (12). Nocturia is also found to be associated with aging and medications such as diuretics and analgesics (12). However, nocturia can signify possible contribution of numerous systemic disorders, such as diabetes mellitus, diabetes insipidus, anorexia nervosa, congestive heart failure causing peripheral edema, hypertension, obesity, renal disorders, and $\operatorname{OSAS}(3,12)$.

In the literature, many studies have shown that nocturia was associated with OSAS and nocturia reduced health-quality and increased morbidity in OSA patients, but the mechanisms causing nocturia in patients with OSA have not been fully explained by these studies $(8,9,10)$. Yoshimura et al. (7) found that both night-time urine production and ANP excretion are elevated in OSAS patients, and they claimed that the obstructive respiratory events created negative intrathoracic pressure, caused the heart to receive a signal of volume overload and resulted in an increase in ANP release. The hormonal response to this signal is increased ANP secretion which may be associated with urine urinary production at night $(6,7)$. In the literature, the prevalence of nocturia in OSAS has been reported to range between $47 \%$ and $75 \%(9,13,14)$. Our findings are similar with the previous reports as we found the rate of $60.8 \%$ in patients with OSAS. In a large sleep study, Romero et al. (15) have demonstrated that the positive predictive value was $85 \%$ and $81 \%$ in snoring and nocturia, respectively and they concluded that nocturia was comparable to snoring as a screening tool for OSAS. Raheem et al. (16) have showed age and AHI score as predictors of nocturia in patients with OSAS. Additionally, in their study, Ayik et al. (17) have shown that the frequency of nocturia increased as the severity of OSA increased. We also found a significant correlation between nocturia and OSAS severity in concordance with these previous reports. All these data support the hypothesis that nocturia may be used as a predictive symptom of OSAS and may be kept in mind in the evaluation of patients with OSAS. There are controversial results as to male or female predominance in nocturia $(12,13)$. In the present study, we found no difference in the prevalence of nocturia between both sexes. However, the association between frequency of nocturia and severity of OSAS was more pronounced in females than in males as mentioned above. This may be confounding because of the relative low number of patients included in the present study. Nevertheless; one should see that this condition affects both sexes. In the literature, there are many studies with regard to the effect of age on the frequency of nocturia and OSAS. The prevalence of nocturia and OSAS increases with age. The prevalence of nocturia increases with age, from $3.4 \%$ in men younger than 30 years to $32.4 \%$ in men older than 60 years $(2,12)$, likewise, the diagnosis of OSAS peaks between ages 40 and 60 (13). Maeda et al. (18) have demonstrated that OSAS severity was associated with the number of urinations in men younger than 50 years and treatment of OSAS decreased the frequency of nocturia in $85 \%$ of patients with nocturia, however, treatment was most effective in patients with severe AHI. Similarly, in our study, we found that there was a statistically significant difference total AHI score and frequency of nocturia between age groups. However, when we analyzed the relationship between presence of nocturia and severity of OSAS and frequency of nocturia and OSAS severity in the age groups, we found that these relationships were stronger in patients below age 40 than in the other age groups. These findings may result from excluding patients with a history of surgical treatment and drug therapy of $\mathrm{BPH}$, urinary incontinence and overactive bladder from the study. This study is not without limitations as most of the studies. First of all, we did not use frequency-volume charts for defining nocturia but just asked patients if they experience or not in their daily lives. Due to the retrospective nature of the present study, we did not have the chance to use standardized questionnaires for nocturia and lower urinary tract symptoms; therefore, interpretation of the present study requires further validation with future prospective trials. Nevertheless, defining patients with sleep laboratory records for nocturia may provide valuable information when combined with patient history.

\section{Conclusion}

We highlight in this study that, the frequency of nocturia increases as the severity of OSAS increases and especially patients with OSAS below the age of 40 years should be evaluated for nocturia. Particularly, this study aims to increase awareness of nocturia as a potentially complex comorbidity among clinicians when evaluating and treating patients with OSAS, and vice versa.

\section{Ethics}

Ethics Committee Approval: Ethics committee approval was not obtained due to retrospective study.

Informed Consent: Informed consent was not taken because of retrospective study.

Peer-review: Externally peer-reviewed.

\section{Authorship Contributions}

Surgical and Medical Practices: B.i.., A.Ç., H.Ç., Concept: B.I.., Design: B.i., Data Collection or Processing: B.i., O.B., Ö.D., 
Analysis or Interpretation: B.i., Literature Search: B.i., Writing: B.i.., O.B., Ö.D.

Conflict of Interest: No conflict of interest was declared by the authors.

Financial Disclosure: The authors declared that this study received no financial support.

\section{References}

1. Van Kerrebroeck $P$, Abrams $P$, Chaikin $D$, Donovan J, Fonda $D$, Jackson $S$, Jennum $P$, Johnson $T$, Lose $G$, Mattiasson A, Robertson $G$, Weiss $\mathrm{J}$; Standardisation Sub-committee of the International Continence Society. The standardization of terminology in nocturia: report from the Standardization Subcommittee of the International Continence Society. Neurourol Urodyn 2002;21:179-183.

2. Schatzl G, Temml C, Schmidbauer J, Dolezal B, Haidinger G, Madersbacher S. Cross-sectional study of nocturia in both sexes: analysis of a voluntary health screening project. Urology 2000;56:71-75.

3. Abrams P. Nocturia: the major problem in patients with lower urinary tract symptoms suggestive of benign prostatic obstruction (LUTS/BPO). Eur Urol Supplements 2005;3:8-16.

4. Young T, Palta M, Dempsey J, Skatrud J, Weber S, Badr S. The occurrence of sleep-disordered breathing among middle-aged adults. N Engl J Med 1993;328:1230-1235.

5. American Academy of Sleep Medicine. The international classification of sleep disorders, 2nd ed.: diagnostic and coding manual. Westchester, IL: American Academy of Sleep Medicine, 2005.

6. Yalkut D, Lee LY, Grider J, Jorgensen M, Jackson B, Ott C. Mechanism of atrial natriuretic peptide release with increased inspiratory resistance. J Lab Clin Med 1996;128:322-328.

7. Yoshimura K, Nakayama T, Sekine A, Matsuda F Kosugi S, Yamada R, Shimizu Y, Kanematsu A, Yoshimura K, Ogawa 0; Nagahama Cohort Research Group. B-Type Natriuretic Peptide as an Independent Correlate of Nocturnal Voiding in Japanese Women. Neurourol Urodyn 2012;31:1266-1271.
8. Yoshimura K, Oka Y, Kamoto T, Yoshimura K, Ogawa O. Differences and assosiations between nocturnal voiding/nocturia and sleep disorders. BJU Int 2010;106:232-237.

9. Moriyama $Y$, Miwa $K$, Tanaka H, Fujihiro S, Nishino $Y$, Deguchi T. Nocturia in men less than 50 years of age may be associated with obstructive sleep apnea syndrome. Urology 2008;71:1096-1098.

10. Margel D, Shochat T, Getzler O, Livne PM, Pillar G. Continuous positive airway pressure reduces nocturia in patients with obstructive sleep apnea. Urology 2006;67:974-977.

11. Iber C, Ancoli-Israel S, Chesson AL Jr, Quan SF. The AASM Manual for the Scoring of Sleep and Associated Events: Rules, Terminology and Technical Specifications. 1st ed. Westchester, IL, USA: American Academy of Sleep Medicine; 2007.

12. Yoshimura K. Correlates for Nocturia: A review of epidemiolagical studies. Int J Urol 2012;19:317-329.

13. Hajduk IA, Strollo PJ Jr, Jasani RR, Atwood CW Jr, Houck PR, Sanders MH Prevalence and predictors of nocturia in obstructive sleep apnea-hypopnea syndrome a retrospective study. Sleep 2003;26:61-64.

14. Kaynak H, Kaynak D, Oztura I. Does frequency of nocturnal urination reflect the severity of sleep-disordered breathing? J Sleep Res 2004;13:173-176.

15. Romero $E$, Krakow $B$, Haynes $P$, Ulibarri V. Nocturia and snoring: Predictive symptoms for obstructive sleep apnea. Sleep Breath 2010;14:337-343.

16. Raheem OA, Orosco RK, Davidson MT, Lakin C. Clinical predictors of nocturia in the sleep apnea population. Urol Ann 2014;6:31-35.

17. Ayik S, Bal K, Akhan G. The association of nocturia with sleep disorders and metabolic and chronic pulmonary conditions: data derived from the polysomnographic evaluations of 730 patients. Turk J Med Sci 2014;44:249254.

18. Maeda $T$, Fukunaga $K$, Nagata $H$, Haraguchi $M$, Kikuchi $E$, Miyajima $A$, Yamasawa W, Shirahama R, Narita M, Betsuyaku T, Asano K, Oya M. Obstructive sleep apnea syndrome should be considered as a cause of nocturia in younger patients without other voiding symptoms. Can Urol Assoc J 2016;10:241-245. 